\title{
Relationship between 25-hydroxyvitamin D levels and inflammatory factors in children with asthma attack
}

\author{
SHANG WANG ${ }^{*}$, YAO PAN ${ }^{*}$ and ZHENKUN ZHANG ${ }^{*}$ \\ Department of Pediatric Respiratory Medicine, The Affiliated Children's Hospital of \\ Xuzhou Medical University, Xuzhou, Jiangsu 221006, P.R. China \\ Received September 18, 2017; Accepted February 27, 2018
}

DOI: $10.3892 /$ etm.2018.5997

\begin{abstract}
The level of 25-hydroxyvitamin D [25-(OH)D] associated with inflammatory factors in children during an asthma attack was investigated. In total, 60 child patients, who were admitted and treated in the Affiliated Children's Hospital of Xuzhou Medical University from March 2015 to March 2017, during their asthma attacks, were selected as the observation group. The patients were divided into the high 25- $(\mathrm{OH}) \mathrm{D}(\mathrm{n}=28)$ and low 25-(OH)D $(n=32)$ groups according to the median level of $25-(\mathrm{OH}) \mathrm{D}$. A total of 30 healthy children were selected as the control group. Biochemical indexes, humoral immunity, the level of tumor necrosis factor- $\alpha$ (TNF- $\alpha$ ) and interleukin-6 (IL-6) contents as well as pulmonary function indexes were examined. The correlations in the levels of 25-(OH)D, IL-6 and TNF- $\alpha$ were also analysed. The results showed that the quantities of leukocytes, neutrophils and eosinophils of patients in the observation group were significantly increased compared with those in the control group $(\mathrm{P}<0.05)$. The contents of IL- 6 and TNF- $\alpha$ in the observation group were obviously higher than those in the normal control group $(\mathrm{P}<0.05)$. The contents of serum IL- 6 and TNF- $\alpha$ in the high $25-(\mathrm{OH}) \mathrm{D}$ group were lower than those in the low 25-(OH)D group 3 days after treatment $(\mathrm{P}<0.05)$. Moreover, the treatment effect in the high $25-(\mathrm{OH}) \mathrm{D}$ group was better than that in the low 25- $(\mathrm{OH}) \mathrm{D}$ group $(\mathrm{P}<0.05)$. In addition, 25- $(\mathrm{OH}) \mathrm{D}$ had a positive correlation with pulmonary function indexes $(\mathrm{P}<0.05)$, while TNF- $\alpha$ and IL-6 were negatively associated with pulmonary function indexes $(\mathrm{P}<0.05)$. The serum $25-(\mathrm{OH}) \mathrm{D}$ level in asthmatic children was negatively associated with the levels of inflammatory factors TNF- $\alpha$ and IL-6.
\end{abstract}

Correspondence to: Dr Zhenkun Zhang, Department of Pediatric Respiratory Medicine, The Affiliated Children's Hospital of Xuzhou Medical University, 18 Sudibei Road, Xuzhou, Jiangsu 221006, P.R. China

E-mail: yl021z@163.com

*Contributed equally

Key words: asthma, 25-(OH)D, inflammation, pulmonary function
The results showed that the level of $25-(\mathrm{OH}) \mathrm{D}$ was decreased in children with asthma attack, which is associated with the inflammatory mediators, IL-6 and TNF- $\alpha$, as well as pulmonary functions $(\mathrm{P}<0.05)$. Therefore, the level of $25-(\mathrm{OH}) \mathrm{D}$ can be used as a test indicator for the prevention and control of childhood asthma.

\section{Introduction}

Asthma is airway hyperreactivity caused by inflammations. Patients with this disease exhibit symptoms such as wheezing, cough, chest tightness, dyspnea and other major symptoms $(1,2)$. In the United States, asthma is the most common cause of hospitalization in the emergency departments (3). According to the survey data in 2010 from the National Center for Health, 80,000 children were diagnosed with asthma at the age of 6 years or below (4).

A number of epidemiological studies have revealed that 25-hydroxyvitamin D [25- $(\mathrm{OH}) \mathrm{D}]$ deficiency is associated with many diseases, especially with the occurrence of asthma symptoms $(5,6)$. Moreover, asthma has a significant correlation with inflammatory factors. This study assessed the potential relationship between $25-(\mathrm{OH}) \mathrm{D}$ level and inflammatory factors in children with asthma attack.

\section{Patients and methods}

Clinical data. A total of 60 child patients, who were admitted and treated in the Pediatric Department of the Affiliated Children'sHospital of Xuzhou Medical University (Xuzhou, China) from March 2015 to March 2017 during their asthma attack were selected as the observation group. There were 29 boys and 31 girls, with an average age of $4.3 \pm 1.4$ years. The children were diagnosed according to the Global Initiative for Asthma (GINA) criteria. This study was approved by the Ethics Committee of the Affiliated Children's Hospital of Xuzhou Medical University, and informed consent was obtained from patients and their families. The serum 25-(OH)D levels of the children were detected, with $14.30 \mathrm{ng} / \mathrm{ml}$ as the median level. Children with a $25-(\mathrm{OH}) \mathrm{D}$ level $>14.30 \mathrm{ng} / \mathrm{ml}$ were included in the high $25-(\mathrm{OH}) \mathrm{D}$ group $(\mathrm{n}=28)$, and those with a $25-(\mathrm{OH}) \mathrm{D}$ level $<14.30 \mathrm{ng} / \mathrm{ml}$ were included in the low $25-(\mathrm{OH}) \mathrm{D}$ group $(\mathrm{n}=32)$. In addition, 30 healthy children were recruited as the control group. There 
Table I. Comparisons of patients' general clinical information.

\begin{tabular}{lcccccr}
\hline & & \multicolumn{2}{c}{ Observation group (n=60) } \\
\cline { 5 - 6 } $\begin{array}{l}\text { General } \\
\text { information }\end{array}$ & $\begin{array}{c}\text { Control } \\
\text { group (n=30) }\end{array}$ & All & $\begin{array}{c}\text { Low 25-(OH)D } \\
\text { group (n=32) }\end{array}$ & $\begin{array}{c}\text { High 25-(OH)D } \\
\text { group (n=28) }\end{array}$ & $\chi^{2}$ & P-value \\
\hline Age (years) & $5.89 \pm 0.82$ & $4.3 \pm 1.4$ & $4.2 \pm 1.1$ & $4.5 \pm 1.5$ & 1.23 & 0.437 \\
Sex (male/total) & $14 / 30$ & $29 / 60$ & $17 / 32$ & $12 / 28$ & 1.983 & 0.130 \\
BMI & $20.31 \pm 1.06$ & $20.83 \pm 1.28$ & $21.08 \pm 1.43$ & $20.65 \pm 1.25$ & 1.534 & 0.582 \\
Allergy (yes/total) & $0 / 30$ & $11(60)^{\mathrm{a}}$ & $6 / 32$ & $5 / 28$ & 2.943 & 0.075 \\
\hline
\end{tabular}

Compared to that in the control group, ${ }^{\mathrm{a}} \mathrm{P}<0.05 .25-(\mathrm{OH}) \mathrm{D}, 25$-hydroxyvitamin $\mathrm{D}$; BMI, body mass index.

was no statistically significant difference for factors including age, sex, body mass index (BMI) and allergic conditions of the children between the two subgroups of the observation group, and data were comparable (Table I).

Treatment methods. The children in the observation group received GINA treatment protocols (7). The appropriate treatment protocol was selected for each child in accordance with the control of asthma.

\section{Index detections}

Examination of 25-(OH)D and biochemical indexes. Prior to the study commencing, fasting venous blood $(10 \mathrm{ml})$ of the observation and control groups was collected in an anticoagulant tube containing EDTA. Following centrifugation for $10 \mathrm{~min}$ at $3,480 \mathrm{x} \mathrm{g}$ at $4^{\circ} \mathrm{C}$, the serum $25-(\mathrm{OH}) \mathrm{D}$ level in the children was examined using ELISA. An automatic hematology analyzer (LH755; Beckman Coulter Biomedical $\mathrm{GmbH}$, Munich, Germany) was utilized to detect the quantities of leukocytes, neutrophils, lymphocytes and eosinophils. The contents of immunoglobulin $\mathrm{G}(\operatorname{IgG})$, immunoglobulin A ( $\operatorname{Ig} \mathrm{A})$ and immunoglobulin $\mathrm{M}$ (IgM) were measured using immune scatter turbidimetry, Behring Nephelometer (BN) specific protein analyzer (CSL Behring, Pensylvania, PA, USA).

Blood of the children $(10 \mathrm{ml})$ in the observation group was drawn at 8 a.m. on day 1, 3 and 7 after treatment, respectively; ELISA was performed to detect the levels of interleukin-6 (IL-6) and tumor necrosis factor- $\alpha$ (TNF- $\alpha$ ) (cat. nos. ab46042 and ab181421; Abcam, Cambridge, MA, USA) in the serum.

Measurement of pulmonary functions. Before the treatment, and on day 1, 3 and 7 after treatment, the RSFJ900 pulmonary function detector (RSDQ; Chongqing, China) was used to measure the forced expiratory volume in $1.0 \mathrm{sec}$ (FEV1.0), peak expiratory flow (PEF), ratio of time to reach peak tidal expiratory flow to total expiratory time (TPTEF/TE) and ratio of volume to PEF and expiratory volume (VPEF/VE).

Statistical analysis. The GraphPad Prism software Version 5.01 (GraphPad Software, Inc., La Jolla, CA, USA) was utilized for statistical analysis. When measurement data were presented as false, the Chi-square test was performed. Analysis of variance (ANOVA) was used for comparisons of differences among multiple groups, and Tukey test was used as post hoc test, and paired t-test was used for analysis on differences between the two groups. Pearson's correlation analysis was utilized to investigate the correlations of the levels of 25-(OH)D, IL-6 and TNF- $\alpha$ with the changes in pulmonary function indexes. Linear regression analysis was applied to analyze the correlation of $25-(\mathrm{OH}) \mathrm{D}$ with IL-6 and TNF- $\alpha . \mathrm{P}<0.05$ was considered to indicate a statistically significant difference.

\section{Results}

Comparisons of patients' general information. As shown in Table I, there were no statistically significant differences in age, sex, BMI and allergic conditions of the asthmatic children between the high and low 25- $(\mathrm{OH}) \mathrm{D}$ groups $(\mathrm{P}>0.05)$. However, the number of allergic patients in the observation group was significantly greater than that in the control group $(\mathrm{P}<0.05)$.

Correlation of serum 25-(OH)D with biochemical indexes. The quantities of leukocytes, neutrophils and eosinophils in patients in the high $25-(\mathrm{OH}) \mathrm{D}$ group were lower than those in the low $25-(\mathrm{OH}) \mathrm{D}$ group $(\mathrm{P}<0.05)$. The quantities of leukocytes, neutrophils and eosinophils in patients in the observation group were significantly increased compared with those in the control group $(\mathrm{P}<0.05)$ (Table II).

Correlation of serum 25-(OH)D with humoral immunity. The levels of $\mathrm{IgG}, \mathrm{IgA}$ and $\operatorname{IgM}$ in the low and high $25-(\mathrm{OH}) \mathrm{D}$ groups were significantly higher than those in the control group $(\mathrm{P}<0.05)$. Moreover, the levels of immunologic factors in the low 25-(OH)D group were elevated compared with those in the high 25- $(\mathrm{OH}) \mathrm{D}$ group $(\mathrm{P}<0.05)$ (Table III).

Variations in serum TNF- $\alpha$ and IL- 6 contents in the three groups of children. As shown in Fig. 1, at the time of the first visit and during 7 days of treatment, the contents of serum IL- 6 and TNF- $\alpha$ in asthmatic children of both the high and low 25-(OH)D groups were significantly higher than those of the normal control group $(\mathrm{P}<0.05)$ with decreasing tendency. At 3 and 7 days after treatment, the serum IL- 6 and TNF- $\alpha$ in the high $25-(\mathrm{OH}) \mathrm{D}$ group was lower compared with that in the low 25-(OH)D group $(\mathrm{P}<0.05)$. 
Table II. Correlation of serum 25-(OH)D with biochemical indexes in child patients.

\begin{tabular}{|c|c|c|c|c|c|c|}
\hline \multirow[b]{2}{*}{$\begin{array}{l}\text { Biochemical } \\
\text { indexes }\left(\text { cells } / \mathrm{mm}^{3} \text { ) }\right.\end{array}$} & \multirow[b]{2}{*}{$\begin{array}{l}\text { Control group } \\
\qquad(\mathrm{n}=30)\end{array}$} & \multirow[b]{2}{*}{$\begin{array}{c}\text { All } \\
(n=60)\end{array}$} & \multicolumn{2}{|c|}{ Observation group $(n=60)$} & \multirow[b]{2}{*}{$\chi^{2}$} & \multirow[b]{2}{*}{ P-value } \\
\hline & & & $\begin{array}{c}\text { Low } 25- \\
(\mathrm{OH}) \mathrm{D} \text { group } \\
(\mathrm{n}=32)\end{array}$ & $\begin{array}{c}\text { High } 25- \\
\text { (OH)D group } \\
(\mathrm{n}=28)\end{array}$ & & \\
\hline No. of leukocytes & $5.89 \pm 0.82$ & $7.23 \pm 2.18^{b}$ & $8.21 \pm 2.71^{\mathrm{c}}$ & $6.67 \pm 1.59^{c}$ & 2.034 & 0.362 \\
\hline No. of neutrophils & $3.32 \pm 0.56$ & $4.01 \pm 1.71^{\mathrm{a}}$ & $5.74 \pm 2.13^{c}$ & $3.68 \pm 1.27^{\mathrm{e}}$ & 2.851 & 0.048 \\
\hline No. of lymphocytes & $1.87 \pm 0.58$ & $2.18 \pm 0.94$ & $2.28 \pm 1.11$ & $2.11 \pm 0.81$ & 1.328 & 0.382 \\
\hline No. of eosinophils & $0.15 \pm 0.09$ & $0.47 \pm 0.43^{\mathrm{b}}$ & $0.49 \pm 0.53^{\mathrm{d}}$ & $0.40 \pm 0.30^{\mathrm{d}}$ & 1.284 & 0.321 \\
\hline
\end{tabular}

The child patients in the observation group compared to those in the control group. ${ }^{\mathrm{a}} \mathrm{P}<0.05 ;{ }^{\mathrm{b}} \mathrm{P}<0.01$, compared to that in the control group; ${ }^{\mathrm{C}} \mathrm{P}<0.05$; ${ }^{\mathrm{d}} \mathrm{P}<0.01$, compared to that in the low $25-(\mathrm{OH}) \mathrm{D}$ group; ${ }^{\mathrm{e}} \mathrm{P}<0.05 .25-(\mathrm{OH}) \mathrm{D}, 25$-hydroxyvitamin $\mathrm{D}$.
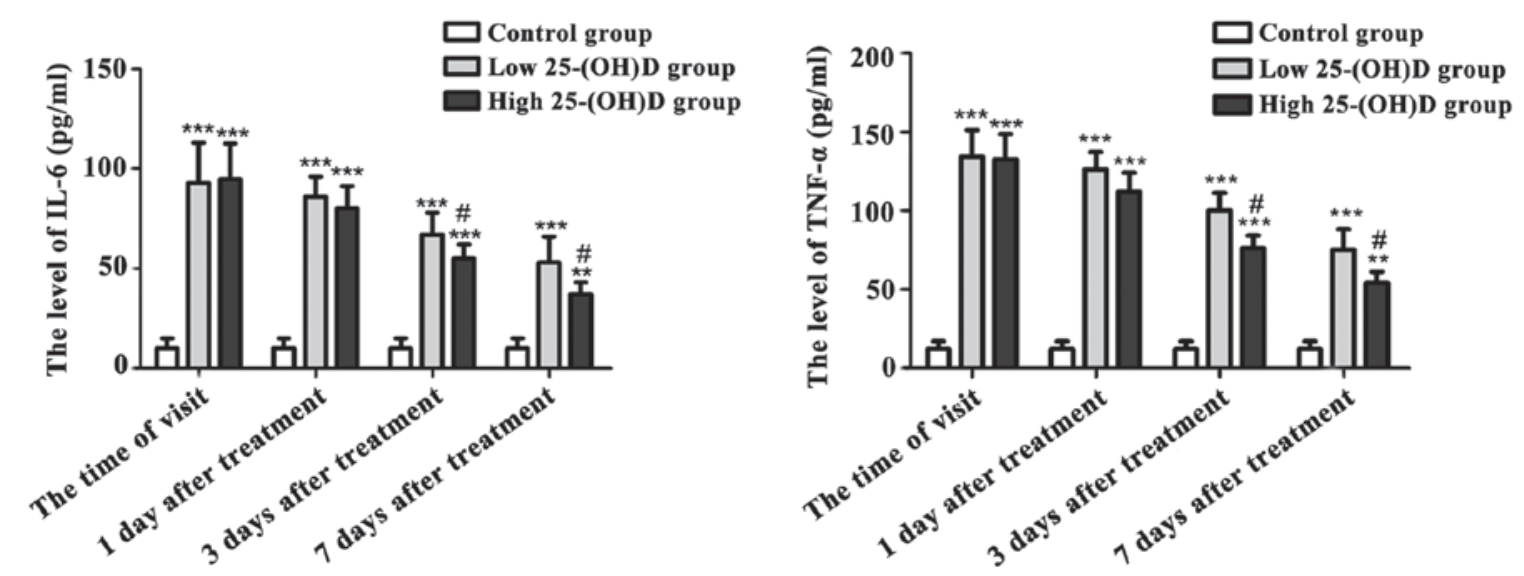

Figure 1. Variations in serum TNF- $\alpha$ and IL- 6 in the three groups of children. ELISA results indicate that the serum IL- 6 and TNF- $\alpha$ in the observation group is obviously higher than that of the normal control group $(\mathrm{P}<0.05)$, with decreasing tendency. At 3 and 7 days after treatment, the serum IL-6 and TNF- $\alpha$ in the high $25-(\mathrm{OH}) \mathrm{D}$ group are lower than those in the low $25-(\mathrm{OH}) \mathrm{D}$ group. Compared with that in the control group, ${ }^{* *} \mathrm{P}<0.01 ;{ }^{* * *} \mathrm{P}<0.001 . \mathrm{Compared}$ with that in the low 25-(OH)D group, ${ }^{\#} \mathrm{P}<0.05$. TNF- $\alpha$, tumor necrosis factor- $\alpha$; IL-6, interleukin-6; 25-(OH)D, 25-hydroxyvitamin D; ELISA, enzyme-linked immunosorbent assay.

Table III. Correlation of serum 25-(OH)D level with immunologic factors (mean $\pm \mathrm{SD}, \mu \mathrm{g} / \mathrm{ml}$ ).

\begin{tabular}{lcccc}
\hline Groups & No. & $\operatorname{IgG}$ & $\operatorname{IgA}$ & $\operatorname{IgM}$ \\
\hline $\begin{array}{l}\text { Control } \\
\text { Low 25- }\end{array}$ & 32 & $\begin{array}{c}8.34 \pm 1.88 \\
\text { (OH)D }\end{array}$ & $\begin{array}{c}1.58 \pm 0.51 \\
\text { (OH.65 }\end{array}$ & $\begin{array}{c}1.22 \pm 0.35 \\
\text { High 25- }\end{array}$ \\
$\begin{array}{l}\text { (OH)D } \\
\text { (OH) }\end{array}$ & $17.28 \pm 2.34^{\mathrm{a}, \mathrm{b}}$ & $6.34 \pm 1.25^{\mathrm{a}, \mathrm{b}}$ & $5.67 \pm 0.84^{\mathrm{a}, \mathrm{b}}$ \\
\hline
\end{tabular}

Comparison with that in the control group, ${ }^{\mathrm{a}} \mathrm{P}<0.05$; compared with that in the low 25-(OH)D group, ${ }^{\mathrm{b}} \mathrm{P}<0.05 .25-(\mathrm{OH}) \mathrm{D}, 25$-hydroxyvitamin $\mathrm{D} ; \mathrm{SD}$, standard deviation.

Variations in pulmonary function indexes. The pulmonary functions of the children with acute attacks in the observation group were monitored, at the time of the visit, as well as on day 1, 3 and 7 after treatment, respectively. The results (Table IV) indicated that the pulmonary functions in the low $25-(\mathrm{OH}) \mathrm{D}$ group were improved on day 3 after treatment, which was manifested as increased PEF, TPTEF/TE and VPEF/VE compared with those at the time of the visit. However, those indexes in the high $25-(\mathrm{OH}) \mathrm{D}$ group were improved on day 1 after treatment, which was manifested as increases in TPTEF/TE and VPEF/VE compared with those at the time of the visit $(\mathrm{P}<0.05)$. Moreover, the treatment effect in the high $25-(\mathrm{OH}) \mathrm{D}$ group was better than that in the low $25-(\mathrm{OH}) \mathrm{D}$ group $(\mathrm{P}<0.05)$.

Correlations of 25-(OH)D, IL-6 and TNF- $\alpha$ levels with the changes in the pulmonary function indexes in asthmatic children. Pearson's correlation analysis was conducted for the levels of 25-(OH)D, IL-6 and TNF- $\alpha$ as well as the pulmonary function indexes in asthmatic children on day 7 after treatment. The results (Table V) showed that 25-(OH)D had a positive correlation with the pulmonary function indexes $(\mathrm{P}<0.05)$, while TNF- $\alpha$ and IL-6 were negatively associated with the pulmonary function indexes $(\mathrm{P}<0.05)$.

Correlation analyses of 25-(OH)D with IL-6 and TNF- $\alpha$ in asthmatic children. Correlation analysis was conducted for the levels of serum $25-(\mathrm{OH}) \mathrm{D}$, TNF- $\alpha$ and IL-6 in asthmatic 
Table IV. Variations in pulmonary function indexes of patients before and after treatment.

\begin{tabular}{llccccc}
\hline Groups & \multicolumn{1}{c}{ Time } & No. & FEV1.0 (1) & PEF (1/min) & TPTEF/TE & VPEF/VE \\
\hline Control & & 30 & $3.92 \pm 0.21$ & $10.21 \pm 1.85$ & $32.43 \pm 2.36$ & $33.87 \pm 2.26$ \\
Low 25-(OH)D & At the time of visit & 32 & $2.03 \pm 0.24$ & $3.02 \pm 0.57$ & $13.15 \pm 1.32$ & $15.25 \pm 1.11$ \\
& 1 day after treatment & & $2.15 \pm 0.31$ & $3.86 \pm 0.84$ & $14.76 \pm 1.60$ & $16.32 \pm 1.52$ \\
& 3 days after treatment & & $2.58 \pm 0.54$ & $4.53 \pm 1.05^{\mathrm{a}}$ & $17.05 \pm 1.72^{\mathrm{a}}$ & $18.05 \pm 1.87^{\mathrm{a}}$ \\
& 7 days after treatment & & $2.74 \pm 0.38^{\mathrm{a}}$ & $5.29 \pm 1.54^{\mathrm{a}}$ & $22.53 \pm 2.04^{\mathrm{b}}$ & $22.35 \pm 2.43^{\mathrm{a}}$ \\
& At the time of visit & 28 & $2.08 \pm 0.17$ & $3.30 \pm 0.66$ & $12.53 \pm 1.51$ & $19.65 \pm 1.84^{\mathrm{a}, \mathrm{c}}$ \\
& 1 day after treatment & & $2.26 \pm 0.30$ & $4.01 \pm 0.82$ & $17.94 \pm 2.73^{\mathrm{a}}$ & $19.65 \pm 1.84^{\mathrm{a}, \mathrm{c}}$ \\
& 3 days after treatment & & $3.01 \pm 0.25^{\mathrm{a}, \mathrm{c}}$ & $5.84 \pm 1.25^{\mathrm{a}, \mathrm{c}}$ & $24.62 \pm 2.94^{\mathrm{a}, \mathrm{c}}$ & $24.46 \pm 3.85^{\mathrm{a}, \mathrm{c}}$ \\
& 7 days after treatment & & $3.54 \pm 0.37^{\mathrm{a}, \mathrm{c}}$ & $6.92 \pm 1.07^{\mathrm{b}, \mathrm{c}}$ & $28.68 \pm 3.51^{\mathrm{a}, \mathrm{c}}$ & $30.01 \pm 3.94^{\mathrm{a}, \mathrm{c}}$ \\
\hline
\end{tabular}

Compared with that at the time of visit, ${ }^{\mathrm{P}} \mathrm{P}<0.05,{ }^{\mathrm{b}} \mathrm{P}<0.01$; compared with that in the low $25-(\mathrm{OH}) \mathrm{D}$ group, ${ }^{\mathrm{c}} \mathrm{P}<0.05$. $\mathrm{PEF}$, peak expiratory flow, $\mathrm{TPTEF} / \mathrm{TE}$, ratio of time to reach peak tidal expiratory flow to total expiratory time; VPEF/VE, ratio of volume to PEF and expiratory volume; FEV1.0, forced expiratory volume in $1.0 \mathrm{sec}$.

Table V. Correlation analyses of levels of 25-(OH)D, IL-6 and TNF- $\alpha$ with pulmonary function indexes in asthmatic children.

\begin{tabular}{|c|c|c|c|c|c|c|}
\hline \multirow{2}{*}{$\begin{array}{l}\text { Pulmonary } \\
\text { function index }\end{array}$} & \multicolumn{2}{|c|}{$25-(\mathrm{OH}) \mathrm{D}$} & \multicolumn{2}{|c|}{ TNF- $\alpha$} & \multicolumn{2}{|c|}{ IL-6 } \\
\hline & r-value & P-value & r-value & P-value & r-value & P-value \\
\hline FEV1.0 & 0.763 & $<0.05$ & -0.693 & $<0.05$ & -0.668 & $<0.05$ \\
\hline $\mathrm{PEF}$ & 0.618 & $<0.05$ & -0.635 & $<0.05$ & -0.775 & $<0.05$ \\
\hline TPTEF/TE & 0.821 & $<0.05$ & -0.743 & $<0.05$ & -0.612 & $<0.05$ \\
\hline VPEF/VE & 0.714 & $<0.05$ & -0.644 & $<0.05$ & -0.603 & $<0.05$ \\
\hline
\end{tabular}

25-(OH)D, 25-hydroxyvitamin D; TNF- $\alpha$, tumor necrosis factor- $\alpha$; IL-6, interleukin-6; PEF, peak expiratory flow, TPTEF/TE, ratio of time to reach peak tidal expiratory flow to total expiratory time; VPEF/VE, ratio of volume to PEF and expiratory volume; FEV1.0, forced expiratory volume in $1.0 \mathrm{sec}$.

children on day 7 after treatment. As shown in Table VI, the serum 25-(OH)D level in asthmatic children was negatively associated with the levels of inflammatory factors TNF- $\alpha$ and IL-6 $(\mathrm{P}<0.05)$.

\section{Discussion}

Previous findings have shown that $25-(\mathrm{OH}) \mathrm{D}$ is a positive regulatory factor for innate and adaptive immune systems, which can regulate various immune cells, such as monocytes, macrophages, lymphocytes and epithelial cells $(7,8)$. In addition, 25-(OH)D can influence pulmonary functions by mediating the macrophages (9). Recent clinical studies have indicated that high-level 25-(OH)D is associated with good pulmonary functions, which can ameliorate the glucocorticoid response (10). It is known that $25-(\mathrm{OH}) \mathrm{D}$ deficiency is prevalent in child patients with mild to moderate persistent asthma, accompanied with the possibility of serious deterioration (11). Epidemiological studies have revealed that intake of VitD during pregnancy can lower the incidence rate of asthma in children (12). According to the suggestions of the National Center for Health, the ideal level of serum 25-(OH)D in healthy children is $\geq 30-40 \mathrm{ng} / \mathrm{ml}(75-100 \mathrm{nmol} / \mathrm{l})$ (13). In
Table VI. Regression analyses on 25-(OH)D, IL-6 and TNF- $\alpha$ in asthmatic children.

\begin{tabular}{lccc}
\hline $\begin{array}{l}\text { Inflammatory } \\
\text { factor }\end{array}$ & $\begin{array}{l}\text { Regression } \\
\text { coefficient }\end{array}$ & t-value & P-value \\
\hline TNF- $\alpha$ & -1.42 & 2.76 & $<0.05$ \\
IL-6 & -1.88 & 3.04 & $<0.05$ \\
\hline
\end{tabular}

TNF- $\alpha$, tumor necrosis factor- $\alpha$; IL-6, interleukin-6.

the present study, it was found that the overall level of serum $25-(\mathrm{OH}) \mathrm{D}$ in asthmatic children was lower than that in the healthy controls. Detection of the pulmonary function indexes suggested that the pulmonary functions in the low 25-(OH)D group were improved at 3 days after treatment, while those in the high $25-(\mathrm{OH}) \mathrm{D}$ group were improved at 1 day after the treatment. In addition, the serum $25-(\mathrm{OH}) \mathrm{D}$ level had a positive correlation with pulmonary functions.

Asthma and airway inflammation are triggered by cytokines associated with T helper cell type 2, such as IL-4, IL-6 and IL-13 (14). In particular, IL-6 and IL-13 play important 
roles in the development of airway hyperreactivity (15). Moreover, the synergistic effects between the synthesis of specific immunoglobulin E and airway remodeling can lead to the formation of IL- 6 receptor $\alpha$-subunit, further inducing the occurrence of inflammations $(16,17)$. The research by Hinks et al (18) revealed that the increased TNF- $\alpha$, IL-6 and IL-13 levels can obviously induce the occurrence of asthma and skin inflammations in the animal models. In addition, $25-(\mathrm{OH}) \mathrm{D}$ has the function of immunoregulation and host defense in addition to its influence on calcium and skeletal balance. Simpson et al found that $25-(\mathrm{OH}) \mathrm{D}$ can overcome the glucocorticoid response in patients with severe asthma by virtue of IL-10, which is an immunologic factor for cluster of differentiation $4+$ T cell expressions (19). In addition, 25-(OH)D has a negative correlation with the severity of allergy and asthma, including a number of eosinophils, markers of serum IgE level and TNF- $\alpha$ level $(20,21)$.

In the present study, the quantities of leukocytes, neutrophils and eosinophils in patients were increased compared with those in the control group, and the indexes in the high 25- $(\mathrm{OH}) \mathrm{D}$ group were lower than those in low 25-(OH)D group. However, there was no difference in lymphocytes between the two groups, which may owing to a relatively small number of participants in the two groups. The Pearson's correlation analysis revealed that the $25-(\mathrm{OH}) \mathrm{D}$ level had a positive correlation with the pulmonary function indexes. By contrast, the inflammatory factors TNF- $\alpha$ and IL-6 were negatively asociated with the pulmonary function indexes.

In conclusion, findings of the present study have shown that the level of 25-(OH)D was decreased in children suffering from asthma attack, which was associated with the inflammatory mediators, IL- 6 and TNF- $\alpha$, as well as pulmonary functions. Therefore, the level of 25-(OH)D can be employed as an indicator for the prevention and control of childhood asthma.

\section{Acknowledgements}

Not applicable.

\section{Funding}

No funding was received.

\section{Availability of data and materials}

The datasets used and/or analyzed during the present study are available from the corresponding author on reasonable request.

\section{Authors' contributions}

SW wrote the manuscript and helped with measurement of pulmonary functions. YP and ZZ contributed to index detections and statistical analysis. All authors read and approved the final manuscript.

\section{Ethics approval and consent to participate}

This study was approved by the Ethics Committee of the Affiliated Children's Hospital of Xuzhou Medical University
(Xuzhou, China) and informed consent was obtained from patients and their families.

\section{Consent for publication}

Not applicable.

\section{Competing interests}

The authors declare that they have no competing interests.

\section{References}

1. National Asthma Education and Prevention Program: Expert Panel Report 3 (EPR-3): Guidelines for the diagnosis and management of asthma-summary report 2007. J Allergy Clin Immunol 120: 94-138, 2007.

2. Fitzpatrick AM, Teague WG, Holguin F, Yeh M and Brown LA: Severe asthma research program: Airway glutathione homeostasis is altered in children with severe asthma: Evidence for oxidant stress. J Allergy Clin Immunol 123: 146-152, 2009.

3. Fitzpatrick AM, Gaston BM, Erzurum SC and Teague WG: National Institutes of Health/National heart, lung, and blood institute severe asthma research program: Features of severe asthma in school-age children: Atopy and increased exhaled nitric oxide. J Allergy Clin Immunol 118: 1218-1225, 2006.

4. Wong GW, Ko FW, Hui DS, Fok TF, Carr D, von Mutius E, Zhong NS, Chen YZ and Lai CK: Factors associated with difference in prevalence of asthma in children from three cities in China: Multicentre epidemiological survey. BMJ 329: 486, 2004.

5. Wjst M, Altmüller J, Braig C, Bahnweg M and André E: A genome-wide linkage scan for 25-OH-D(3) and 1,25-(OH)2-D3 serum levels in asthma families. J Steroid Biochem Mol Biol 103: 799-802, 2007.

6. Chawes BL, Bønnelykke K, Jensen PF, Schoos AM, Heickendorff L and Bisgaard H: Cord blood 25(OH)-vitamin D deficiency and childhood asthma, allergy and eczema: The COPSAC2000 birth cohort study. PLoS One 9: e99856, 2014.

7. Dizier $\mathrm{MH}$, Besse-Schmittler C, Guilloud-Bataille M, Annesi-Maesano I, Boussaha M, Bousquet J, Charpin D, Degioanni A, Gormand F, Grimfeld A, et al: Genome screen for asthma and related phenotypes in the French EGEA study. Am J Respir Crit Care Med 162: 1812-1818, 2000.

8. Cranney A, Horsley T, O'Donnell S, Weiler H, Puil L, Ooi D, Atkinson S, Ward L, Moher D, Hanley D, et al: Effectiveness and safety of vitamin D in relation to bone health. Evid Rep Technol Assess 158: 1-235, 2007.

9. Panda DK, Miao D, Tremblay ML, Sirois J, Farookhi R, Hendy GN and Goltzman D: Targeted ablation of the 25-hydroxyvitamin D $1 \alpha$-hydroxylase enzyme: Evidence for skeletal, reproductive, and immune dysfunction. Proc Natl Acad Sci USA 98: 7498-7503, 2001.

10. Liu PT, Stenger S, Li H, Wenzel L, Tan BH, Krutzik SR, Ochoa MT, Schauber J, Wu K, Meinken C, et al: Toll-like receptor triggering of a vitamin $\mathrm{D}$-mediated human antimicrobial response. Science 311: 1770-1773, 2006.

11. Sutherland ER, Goleva E, Jackson LP, Stevens AD and Leung DY: Vitamin D levels, lung function, and steroid response in adult asthma. Am J Respir Crit Care Med 181: 699-704, 2010.

12. Litonjua AA and Weiss ST: Is vitamin D deficiency to blame for the asthma epidemic? J Allergy Clin Immunol 120: 1031-1035, 2007.

13. van der Meer IM, Karamali NS, Boeke AJ, Lips P, Middelkoop BJ, Verhoeven I and Wuister JD: High prevalence of vitamin D deficiency in pregnant non-Western women in The Hague, Netherlands. Am J Clin Nutr 84: 350-353, quiz 468-469, 2006.

14. Martins D, Wolf M, Pan D, Zadshir A, Tareen N, Thadhani R, Felsenfeld A, Levine B, Mehrotra R and Norris K: Prevalence of cardiovascular risk factors and the serum levels of 25-hydroxyvitamin D in the United States: Data from the Third National Health and Nutrition Examination Survey. Arch Intern Med 167: 1159-1165, 2007.

15. Björnsdottir US and Cypcar DM: Asthma: An inflammatory mediator soup. Allergy 54: 55-61, 1999. 
16. Jayaram L, Pizzichini E, Lemière C, Man SF, Cartier A, Hargreave FE and Pizzichini MM: Steroid naive eosinophilic asthma: Anti-inflammatory effects of fluticasone and montelukast. Thorax 60: 100-105, 2005.

17. Beasley R, Roche W and Holgate ST: Inflammatory processes in bronchial asthma. Drugs 37: 117-122, discussion 127-136, 1989.

18. Hinks TSC, Brown T, Lau LC, Rupani H, Barber C, Elliott S, Ward JA, Ono J, Ohta S, Izuhara K, et al: Multidimensional endotyping in patients with severe asthma reveals inflammatory heterogeneity in matrix metalloproteinases and chitinase 3-like protein 1. J Allergy Clin Immunol 138: 61-75, 2016.

19. Simpson JL, Scott R, Boyle MJ and Gibson PG: Inflammatory subtypes in asthma: Assessment and identification using induced sputum. Respirology 11: 54-61, 2006.
20. Vilarrasa N, Vendrell J, Maravall J, Elío I, Solano E, San José P, García I, Virgili N, Soler J and Gómez JM: Is plasma 25(OH) D related to adipokines, inflammatory cytokines and insulin resistance in both a healthy and morbidly obese population? Endocrine 38: 235-242, 2010.

21. PetersonCAandHeffernanME: Serumtumornecrosisfactor-alpha concentrations are negatively correlated with serum $25(\mathrm{OH}) \mathrm{D}$ concentrations in healthy women. J Inflamm (Lond) 5: 10, 2008.

This work is licensed under a Creative Commons Attribution-NonCommercial-NoDerivatives 4.0 International (CC BY-NC-ND 4.0) License. 